\title{
ORIGINAL ARTICLE \\ Infectious disease, public health, and politics: United States response to Ebola and Zika
}

\author{
Phillip M. Singer ${ }^{1} \cdot$ Charley E. Willison ${ }^{2} \cdot$ Scott L. Greer ${ }^{3}$ \\ Published online: 3 August 2020 \\ ๑) Springer Nature Limited 2020
}

\begin{abstract}
Politics, rather than disease characteristics, complicated the United States response to Ebola virus disease and Zika virus. We analyze how media and political elites shaped public opinion of the two outbreaks. We conducted a retrospective analysis of media coverage, Congressional floor speech, and public opinion polls to explain elite cueing and public perceptions of Ebola and Zika. We find evidence of elite cueing by Congress and the media on public opinion. Public opinion of both disease outbreaks initially followed partisan patterns. However, while Ebola public opinion remained partisan, ultimately, opinion emerged of a bipartisan nature for Zika, mirroring elite framing. Public health officials should be aware of how elite cueing shapes policy and prioritizes partisan strategies. Politics and public opinion can focus attention on or away from infectious disease; it can also undermine public health responses by biasing the public's view of a diseases' relative risk.
\end{abstract}

Keywords Public health policy $\cdot$ Natural disaster response $\cdot$ Public health politics · Response to Ebola virus · Response to Zika virus

Phillip M. Singer

phillip.singer@poli-sci.utah.edu

Charley E. Willison

willison@hcp.med.harvard.edu

Scott L. Greer

slgreer@umich.edu

1 Political Science Department, University of Utah, 260 S. Central Campus Dr. Room 3345,

Salt Lake City, UT 84112, USA

2 Department of Health Care Policy, Harvard University, 180 Longwood, Boston, MA 02115, USA

3 Department of Health Management and Policy, University of Michigan School of Public Health, 1415 Washington Heights, Ann Arbor, MI 48109, USA 


\section{Introduction}

Factors independent of virology and epidemiology complicated the United States' (US) response to the 2014 Ebola virus disease (hereafter Ebola) outbreak and the 2016 appearance of Zika virus in the Western Hemisphere [1, 2]. Contracting Ebola is uncommon, but when an individual is infected the results are often fatal, with half of cases ending in death [3]. Symptoms progress from fever and body pain, to gastrointestinal symptoms resulting in substantial loss of bodily fluids that transmit the disease to others [4]. Federal public health leaders supported a strategy of addressing Ebola globally when an outbreak occurred in West Africa. But a US Congress that refused to allocate funds to address the disease until after 2014 midterm elections repeatedly undercut their efforts.

Two years later the US faced an outbreak of Zika on its own territory and the first-ever official warning against domestic United States travel, when its Centers for Disease Control and Prevention (CDC) advised women who might be pregnant to avoid Miami, the country's seventh-largest city [5]. Most individuals infected by Zika have no signs or symptoms; when symptoms do appear, they are usually acute, though short in duration [6]. Zika infection during pregnancy caused the harshest outcomes, severe birth defects in 5-10\% of pregnancies [7]. Despite the threat posed by this mosquito-borne illness and the serious weakness of local public health infrastructures in at-risk states [8], the United States' federal government's budgetary response came almost a year after identification of the first cases, with far less funding than the Obama administration requested [9, 10].

We use the US as a case study to understand the connections between politics, public opinion, and public health. Public health professionals globally often overlook the important ways in which politics and public opinion affect policymakers' responses to disease outbreaks, and how the public perceives relative risks of disease outbreaks $[11,12]$. To analyze these connections, we compare the frequency and timing of the political and media elites' speech about both disease outbreaks and compare those variations to the way public opinion evolved.

We ground our analysis in elite theory. It holds that a small subset of a population has an outsized effect on the broader public opinion through persuasion and manipulation $[13,14]$. The political context in each nation influences the types of elites that matter in a policy debate [15]. We conduct our analysis at the national level. For the US, we define 'political elites' as members of either the US House of Representatives or the US Senate that make up the US Congress, the national legislative body; and 'media elites' as national cable news channels.

We focus on political elites' communication and shaping of public opinion, a process called political 'cueing'. That is, the public takes its 'cues' from the opinions of experts, often through the media and political elites [16]. Cueing by elites, especially by hyper-partisan US cable news channels such as Fox News and MSNBC, can shape how the public understands events [17-19].

Political elites drive opinions and attitudes, while polarization and partisanship direct the public to policymakers and media that fit their political outlooks 
[20]. Others have applied these connections to pollution and immigration policy [21-23]; there has been less research on the role of elite cueing and media coverage on the public's view of communicable diseases.

The political institutions of a country influence the political incentives available to elected officials. Political elites take positions with which the public agrees, try to influence the public to agree with their positions, send partisan messages to cast doubt on the performance of opponents, and claim credit for good events [24-26]. These incentives shape how elites respond to disease outbreaks-informing when and whether to emphasize a disease in shaping public opinion.

Some claim that health politics is different from the politics of other policy areas on some dimensions (funding, deservingness, and redistributive claims) [27, 28]. Yet, we see evidence of traditional party politics, polarization, and partisanship in health politics in the US [29]. For a decade, public views on health care and health policy have consistently shown divisions along partisan lines and the divisions between elected officials from different political parties and political party identification by the public have increased over time [30].

US political institutions diffuse power and there is a well-documented public tendency to hold the president, the most visible politician in the country, responsible for policy failures [31, 32]. With President Barack Obama in office during both disease outbreaks, Republicans and conservative media focused their dissatisfaction with the federal government's response on the president. Republicans controlled both chambers of the legislature (House of Representatives and Senate) for part (Ebola) or all (Zika) of the disease outbreak, dividing its members between those who cast partisan blame and those who wanted credit for productive action to address their constituents' problems. Such conflicts in party politics may yield ineffective or inadequate disaster responses.

The characteristics of the disease itself-etiology, mode of transmission, and populations at-risk-influence elite messaging about outbreaks. The Ebola outbreak occurred largely in West Africa. Public health in US focused on avoiding creation of reservoirs of the disease in other nations that might create a persistent threat to the US [33, 34]. Ebola did not concentrate in any specific US geographic area and the risk pertained mainly health care providers. Even so, the nature of the Ebola virus, its symptoms, how it spread, and the death rate, attracted political and media elites to discuss it at length.

The Zika outbreak differed from Ebola in two ways: (1) Zika is a threat based on geography, whereas it was health care workers who transmitted Ebola in the US. Initially, Zika risk concentrated in the southern United States. Mosquitoes, the agent responsible for transmitting Zika, seek stagnant water for breeding, and if more such reservoirs exist in lower resource settings, disparities follow for who is most acutely at risk. Once hatched, those mosquitoes travel throughout a region placing the broader population at risk of infection [35]. In principle, this would make Zika more alarming to voters who live in those areas. (2) While the President at the time of the outbreak was a Democrat, more Republicans represented the states and districts initially most at risk.

Polarization, partisanship, political incentives, and elites exist around the world. Understanding the connections between party politics, elite 
communication, and how the nature of a disease outbreak shapes the public's views of public health emergencies is important for understanding public health policy. In our ever more connected world, the likelihood and risks of infectious disease outbreaks are increasing, as evidenced by the coronavirus disease pandemic in 2020 [36]. Understanding the politics that shape the government response to disease can help improve a country's public health policy and response [11].

In this study we offer a comparison of frequency of public speech by elites' and public opinion responses to Ebola and Zika as an opportunity to understand the cueing of infectious disease outbreaks and to categorize differences in response from elites and the public for the two types of diseases. Public perceptions of the outbreaks often align with media and political elite cues. We focus on the ways those cues are shaped by party politics and electoral strategies, the political institutional landscape, and the nature of the diseases.

\section{Methods}

We examine the frequency and timing of two sources of elite cueing that influence voter responses and interpretation of infectious disease outbreaks: national cable news coverage and Congressional floor speech [37]. These sources represent ways media and political elites' communicate about the federal responses to Ebola and Zika and their influence on the public.

Cable news coverage is a niche part of the media that is disproportionately consumed by political elites [38]. Researchers have linked cable news to shaping governmental responses to problems $[39,40]$. Thus, we compare the conservative Fox News network, with enormous influence among Republicans, to the smaller and liberal MSNBC network. To examine whether the networks covered Zika and Ebola differently, we collected and analyzed LexisNexis (now NexusUni) data on the timing and frequency of coverage over an 18-month period (we collected data on Ebola from April 2014 to September 2015 and on Zika from September 2015 to February 2017) for both disease outbreaks [41, 42]. For the final analysis we included only substantive coverage of each outbreak, excluding unrelated mentions of the diseases by the news providers.

During the same time period we collected and analyzed Congressional 'floor speeches', statements of priority through which political elites frame discussions. The quantity, partisan distribution, and timing of floor speeches provide information about how policymakers and parties seek to make information salient to others [43]. We then compared these elite signals with results from four organizations conducting nationally representative public opinion surveys that included questions about the disease outbreaks. Survey data with questions about Ebola came from Fox News and CNN during 2014 and survey questions on Zika from The Economist and Morning Consult in 2016. Our analysis of these surveys followed shifts in public perceptions over time, how they differed for Ebola and Zika, and the political party of the respondent. 


\section{Results}

\section{Cable TV news: comparing Ebola and Zika}

We found several key differences in the frequency and timing of news coverage. Cable news broadcasts began covering the Ebola outbreak much more frequently compared to their coverage of Zika (See Fig. 1a, c). Fox News and MSNBC coverage together mentioned Ebola nearly seven hundred times. The buildup of cable news coverage of Ebola occurred during the summer of 2014 along with the first cases in the United States. Cable news coverage reached its peak in October 2014, on the eve of the 2014 midterm election for the US Congress. After the elections, cable coverage of Ebola slowed, even as the threat of Ebola continued globally and in the US. The Zika outbreak received far less cable news coverage. There were 133 mentions of Zika by Fox News and MSNBC combined, with coverage of the outbreak peaking during the summer of 2016. Coverage of Zika did not increase prior to the 2016 presidential election in the United States and dissipated in the fall of 2016.

We also found evidence of differences in coverage between the two cable news channels. Both networks covered Ebola more than Zika. Fox News devoted more airtime to the disease outbreaks overall: it covered Ebola and Zika 477 times. MSNBC covered the diseases 341 times. Fox News began covering the Ebola outbreak earlier than MSNBC, airing its first story within 4 months of the outbreak in West Africa, but before any cases occurred in the United States. Both networks began coverage of the Zika outbreak more slowly. Coverage began 10 months after the World Health Organization warned about the disease. Coverage of Zika did not track with spread of the disease; the politics of federal government funding for the Zika outbreak drove media coverage.

\section{Congressional floor speech: comparing Ebola and Zika}

There are two primary differences between cable news coverage and Congressional floor speech for Ebola and Zika. First, members of Congress talked more about Zika, in more than 600 instances in floor speeches (See Fig. 1b, d), compared to 129 for Ebola. The protracted nature of the funding debate drove the response to the Zika outbreak. In February 2016, President Obama formally requested $\$ 1.86$ billion funding from Congress to combat the Zika outbreak [44]; Congress appropriated $\$ 1.1$ billion in September 2016. Between the request and enactment of the funding bill, Republicans and Democrats traded proposals laden with unrelated partisan amendments, including a Republican request for Confederate flags to fly at military cemeteries. Congressional floor speech reflected the initial partisan nature of the Zika funding request and political disagreement between Republicans and Democrats over whether and how much the federal government should appropriate to respond to the disease. 


\section{Ebola}

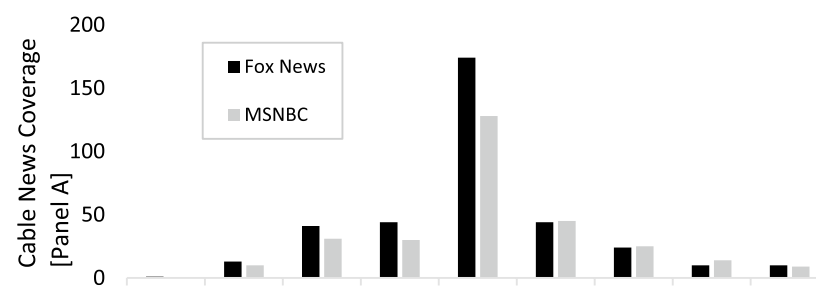

Jun-14 Jul-14 Aug-14 Sep-14 Oct-14 Nov-14 Dec-14 Jan-15 Feb-15 Mar-15 Apr-15 May-15 Jun-15
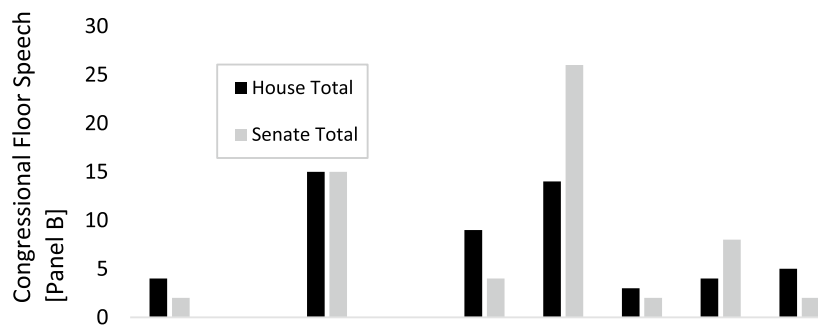

Jun-14 Jul-14 Aug-14 Sep-14 Oct-14 Nov-14 Dec-14 Jan-15 Feb-15 Mar-15 Apr-15 May-15 Jun-15

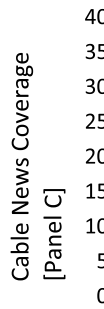

Zika

- Fox News

$\square$ MSNBC

- House Total

Senate Total

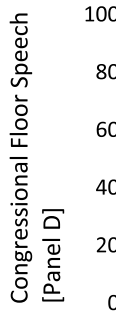

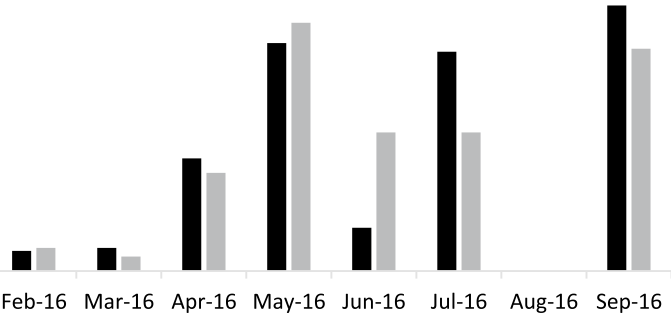

Fig. 1 Cables news coverage and congressional floor speech of Ebola (June 2014-June 2015) and Zika (October 2015-September 2016

Second, unlike the cable news on Ebola with consistent partisan messages, initial partisanship on Zika dissipated. The nature of the disease itself and shifts in the political landscape drove this Congressional shift towards bipartisanship. 
Party politics shaped Congressional speech about both outbreaks. During the Ebola outbreak, Republicans had majority control in the House of Representatives, but not in the Senate. Republicans opposed the federal government's response to Ebola much more vocally. They blamed Democrats in an effort to win majority control of the Senate during the upcoming election.

By the time of the Zika outbreak, party politics had shifted in the House of Representatives. Democrats (even with a Democrat as President) had become the minority party there. All federal funding requires Congressional action, not just presidential action. As Republicans tried to attach partisan amendments to funding bills, Democrats drew attention to Republican amendments and did not accede to pressure to capitulate.

During the Zika outbreak Democrats spoke earlier and more frequently about Republican amendments and the Republicans' failure to pass a 'clean' funding bill free of unrelated amendments. Republicans in districts and states initially most at risk of Zika spurred Republican Congressional speech. Unlike with Ebola, the concentrated risk of transmission led to a bipartisan approach to Zika. When Congress eventually passed a clean funding bill in H.R. 5325 in September 2016 , it was with support of $70 \%$ of Republicans and $90 \%$ of Democrats in the House and Senate [45], a contrast to the partisan voting patterns of funding for Ebola [46].

\section{Public opinion surveys: how public opinion corresponds to elite communications}

Having highlighted how media and political elite cueing varied between the Ebola and Zika outbreaks, we connect those differences to public opinion. For Ebola we find consistent partisan sorting amongst the general public. Registered Republican voters expressed concerns over the Obama administration's handling of the Ebola outbreak more frequently; $65 \%$ of registered Democratic voters and $19 \%$ of Republican's supported the president's actions [47]. Forty-seven percent of registered Democratic voters were "very confident" that the federal government could prevent a nationwide epidemic of Ebola; among Republican voters, just $16 \%$ expressed such confidence [48]. More Republicans believed that Ebola would spread in the United States; $56 \%$ believed it was "very likely", compared to $36 \%$ of Democratic voters [48].

Zika initially followed partisan sorting by the public. With Republican majorities in control of both chambers of Congress, Democratic voters responded twice as often that they were "very concerned" about a Zika epidemic in the US and about their individual likelihood of contracting Zika [49, 50]. Views of the public became more bipartisan as Republican members of Congress began calling for funding the government response to Zika. Prior to passage of the Congressional funding package, a majority of both Democratic and Republican voters, $70 \%$ and $59 \%$ respectively, supported immediate federal action for the Zika outbreak [51] and $81 \%$ of Democrats and $76 \%$ of Republicans supported Congressional appropriations for additional Zika funding [52]. 


\section{Discussion}

We analyzed the role of cueing by political and media elites on public opinion about federal responses to two communicable disease outbreaks. We find that elites and the public in the US responded differently to the outbreaks. For Ebola, a partisan response from elites in Congress and the media manifested in the public perception of the outbreaks. For Zika, the US response to Zika eventually shifted towards a bipartisan response from elites and the public. Deficiencies in how the US responded to these public health disasters can be understood through the connection between politics, public opinion, and public health.

Electoral strategies and perceived threats may explain the divergence in elite cueing and public opinion. During the Ebola outbreak, Republicans and conservative media considered casting blame on the president to be a politically advantageous strategy: upcoming 2014 Congressional midterm elections offered an opportunity to gain control of the Senate. Republicans connected Ebola to the Obama administration's failure to contain it with broader policies including immigration and border security. Democrats sought to limit damage of Ebola on their electoral chances, largely by avoiding discussion of the outbreak.

For Zika, shifts in the political landscape and differences between the diseases limited Republican efforts to recreate the politics of Ebola. After losing the Congressional majority in 2014, Democrats used their minority status against Republicans' efforts to introduce partisan amendments. Because the disease initially threatened areas of the country represented by Republican members of congress, and an area where presidential candidate Donald Trump owned property, the Republicans' political calculation was more complex. Ultimately, the Zika outbreak allowed Republican policymakers to take credit for voting in favor of aid to their constituents. Media coverage of Zika supported the ultimate bipartisan outcome. Unlike the exciting media story of Ebola, the Zika outbreak remained a budgetary fight within Congress with reduced cable news coverage, partisan sorting, and cueing of the general public.

Partisanship and the politics of blame shape communications and views about disease outbreaks. Thus, these results have important implications for public health practitioners and policy makers globally. Ideally, how a country responds to an infectious disease outbreak would match the severity of the disease.

The COVID-19 pandemic highlights the importance of the politics that shape policy responses to public health disasters. The Trump administration has issued mixed messages about the pandemic's severity, seeking to minimize the risks. States with Republican governors and states with more supporters of President Trump have been slower to adopt social distancing, mirroring the Administration's skepticism [53]. The political roots of COVID-19 inform policy preferences, behaviors, and public opinion about the pandemic [54]. Public health practitioners and policymakers must take political polarization and partisanship into account for planning responses disease outbreaks.

Limitations of the study are twofold. First, we consider only to the United States, although the greater risks of Ebola and Zika largely bypassed the US. 
Second, we did not include a variety of mechanisms by which policymakers can influence public thought, including social media, press releases, and interviews. The generalizability of our results should then be considered within these limitations. Despite these limitations, the connections between politics, public opinion, and public health exist across the globe and public health officials should be aware of how politics shape public health policies.

\section{Conclusions}

This study highlights the important and often overlooked role that political and media elites and the disease play in shaping the public's perception of public health disasters. Our results are particularly important for public health professionals to understand how the politics, political system, and partisanship shape public health policy in response to infectious disease. Partisan cueing by political elites and mass media coverage of the infectious disease influenced how the public interpreted the Zika and Ebola outbreaks in ways consistent with partisan interpretations. It is important not to underestimate the role of political elites and their electoral incentives in shaping public opinion public health policy.

Acknowledgements For the research reported in this publication, we received support from the National Institute of Mental Health of the National Institutes of Health under Award Number T32MH019733. The content is solely the responsibility of the authors and does not necessarily represent the official views of the National Institutes of Health.

\section{References}

1. Greer SL, Singer PM. The United States confronts Ebola: suasion, executive action and fragmentation. J Health Econ Policy Law. 2017;12(1):81-104.

2. Nuzzo JB, Inglesby TV. Ramping up the response to Ebola. N Engl J Med. 2018;379(26):2490-1.

3. World Health Organization. Ebola virus disease; 2020. https://www.who.int/news-room/fact-sheets/ detail/ebola-virus-disease.

4. Feldmann H, Sprecher A, Geisbert TW. Ebola. N Engl J Med. 2020;382(19):1832-42.

5. Centers for Disease Control and Prevention. CDC issues travel guidance related to Miami neighborhood with active Zika spread; 2016. https://www.cdc.gov/media/releases/2016/p0801-zika-trave l-guidance.html.

6. Gatherer D, Kohl A. Zika virus: a previously slow pandemic spreads rapidly through the Americas. J Gen Virol. 2016;97(2):269-73.

7. Centers for Disease Control and Prevention. Data \& Statistics on Zika and Pregnancy; 2019. https:// www.cdc.gov/pregnancy/zika/data/index.html.

8. Baker EL Jr, Potter MA, Jones DL, Mercer SL, Cioffi JP, Green LW, et al. The public health infrastructure and our nation's health. J Annu Rev Public Health. 2005;26:303-18.

9. Winneg KM, Stryker JE, Romer D, Jamieson KH. Differences between Florida and the rest of the united states in response to local transmission of the zika virus: implications for future communication campaigns. Risk Anal. 2018;38(12):2546-60.

10. Greer SL, Singer PM. Addressing Zika in the United States: why so slow? Am J Public Health. 2017;107(6):861-2.

11. Oliver TR. The politics of public health policy. Annu Rev Public Health. 2006;27:195-233.

12. Ribeiro B, Hartley S, Nerlich B, Jaspal R. Media coverage of the Zika crisis in Brazil: the construction of a 'war' frame that masked social and gender inequalities. Soc Sci Med. 2018;200:137-44. 
13. Pareto V. The mind and society. New York City: Harcourt, Brace and Company; 1935.

14. Meisel JH. The Myth of the Ruling Class: Gaetano Mosca and the elite. Ann Arbor: University of Michigan Press; 1958.

15. Parry G. Political elites. Colchester: ECPR Press; 2005.

16. Gilens M, Murakawa N. Elite cues and political decision-making. Res Micropolit. 2002;6:15-49.

17. Shah DV, Watts MD, Domke D, Fan DP. News framing and cueing of issue regimes: explaining Clinton's public approval in spite of scandal. Public Opin Q. 2002;66(3):339-70.

18. Sell TK, Boddie C, McGinty EE, Pollack K, Smith KC, Burke TA, et al. Media messages and perception of risk for Ebola virus infection, United States. Emerg Infect Dis. 2017;23(1):108.

19. Benkler Y, Faris R, Roberts H. Network propaganda: manipulation, disinformation, and radicalization in American politics. New York: Oxford University Press; 2018.

20. Guber DL. Partisan cueing and polarization in public opinion about climate change. Oxford Research Encyclopedia of Climate Science. Oxford: Oxford University Press; 2017.

21. McCombs M. Setting the agenda: mass media and public opinion. Hoboken: Wiley; 2018.

22. Carmichael JT, Brulle RJ. Elite cues, media coverage, and public concern: an integrated path analysis of public opinion on climate change, 2001-2013. Environ Polit. 2017;26(2):232-52.

23. Dunaway J, Branton RP, Abrajano MA. Agenda setting, public opinion, and the issue of immigration reform. Soc Sci Q. 2010;91(2):359-78.

24. Mayhew DR. Congress: the electoral connection. New Haven: Yale University Press; 1974.

25. Weaver RK. The politics of blame avoidance. J Publ Policy. 1986;6(4):371-98.

26. Arnold RD. The logic of congressional action. New Haven: Yale University Press; 1990.

27. Carpenter D. Is health politics different? Annu Rev Polit Sci. 2012;15:287-311.

28. Jensen C, Petersen MB. The deservingness heuristic and the politics of health care. Am J Polit Sci. 2017;61(1):68-83.

29. Jacobs LR, Mettler S. What health reform tells us about American politics. J Health Polit Policy Law. 2020. https://doi.org/10.1017/S1049096510001290.

30. Brodie M, Hamel EC, Kirzinger A, Altman DE. The past, present, and possible future of public opinion on the ACA: a review of 102 nationally representative public opinion polls about the Affordable Care Act, 2010 through 2019. Health Aff. 2020;39(3):462-70.

31. Malhotra N, Kuo AG. Attributing blame: the public's Response to hurricane Katrina. J Polit. 2008;70(1):102-35.

32. Maestas CD, Atkeson LR, Croom T, Bryant LA. Shifting the blame: federalism, media, and public assignment of blame following Hurricane Katrina. Publius. 2008;38(4):609-32.

33. Fauci AS. Ebola-underscoring the global disparities in health care resources. N Engl J Med. 2014;371(12):1084-6.

34. Frieden TR, Damon I, Bell BP, Kenyon T, Nichol S. Ebola 2014-new challenges, new global response and responsibility. N Engl J Med. 2014;371(13):1177-80.

35. Lee CT, Greene SK, Baumgartner J, Fine A. Disparities in Zika virus testing and incidence among women of reproductive age-New York City, 2016. J Public Health Manage Pract. 2018;24(6):533-41.

36. Tatem AJ, Rogers DJ, Hay SI. Global transport networks and infectious disease spread. Adv Parasitol. 2006;62:293-343.

37. Broockman DE, Butler DM. The causal effects of elite position-taking on voter attitudes: field experiments with elite communication. Am J Polit Sci. 2017;61(1):208-21.

38. Clinton JD, Enamorado T. The national news media's effect on Congress: how Fox News affected elites in Congress. J Polit. 2014;76(4):928-43.

39. Barnes MD, Hanson CL, Novilla LM, Meacham AT, McIntyre E, Erickson BC. Analysis of media agenda setting during and after Hurricane Katrina: implications for emergency preparedness, disaster response, and disaster policy. Am J Public Health. 2008;98(4):604-10.

40. Douglas EM. Media coverage of agency-related child maltreatment fatalities: does it result in state legislative change intended to prevent future fatalities? J Policy Pract. 2009;8(3):224-39.

41. Grossmann M, Hopkins DA. Asymmetric politics: ideological republicans and group interest. Democrats: Oxford University Press; 2016.

42. Sell TK, Boddie C, McGinty EE, Pollack K, Smith KC, Burke TA, et al. News media coverage of US Ebola policies: implications for communication during future infectious disease threats. Prev Med. 2016;93:115-20.

43. Peake JS, Eshbaugh-Soha M. The agenda-setting impact of major presidential TV addresses. Polit Commun. 2008;25(2):113-37. 
44. Katz R, Attal-Juncqua A, Fischer JE. Funding public health emergency preparedness in the United States. Am J Public Health. 2017;107(S2):S148-52.

45. United States Congress. H.R. 5325 - Continuing Appropriations and Military Construction, Veteran Affairs, and Related Agencies Appropriations Act, 2017, and Zika Response and Preparedness Act; 2016. https://www.congress.gov/bill/114th-congress/house-bill/5325/all-actions?overview=close $\mathrm{d} \& \mathrm{q}=\{\% 22$ roll-call-vote $\% 22: \% 22$ all $\% 22\} \& \mathrm{KWICView}=$ false.

46. Consolidated and Further Continuing Appropriations Act, 2015, United States Congress, 113th Congress Sess. (2014).

47. Fox News. Fox News Polls: US voters weigh in on ISIS and Ebola: Fox News; 2014. http://www. foxnews.com/politics/interactive/2014/10/15/fox-news-polls-us-voters-weigh-in-on-WoSs-and-ebola /.

48. CNN/ORC. CNN/ORC Poll: CNN; 2014. http://i2.cdn.turner.com/cnn/2014/images/10/27/ebola .poll.7pm.pdf.

49. YouGov/Economist. YouGov/Economist Poll: May 20-23, 2016; 2016. https://today.yougov.com/ topics/politics/articles-reports/2016/05/24/yougoveconomist-poll-may-20-23-2016.

50. YouGov/Economist. YouGov/Economist Poll: August 6-9, 2016; 2016. https://today.yougov.com/ news/2016/08/09/yougoveconomist-poll-august-6-9-2016/.

51. Owens C. Poll: Federal Government Should Act Immediately on Zika Morning Consult; 2016. https ://morningconsult.com/2016/08/03/poll-federal-government-should-act-immediately-on-zika/.

52. McIntire ME. Poll: Voters Support Zika Bill, but Less Sure on 'Poison Pills': Morning Consult; 2016. https://morningconsult.com/2016/07/06/zika-conference-bill-national-voter-survey/.

53. Adolph C, Amano K, Jensen-Bang B, Fullman N, Wilkerson J. Pandemic Politics: Timing StateLevel Social Distancing Responses to COVID-19. In: Washington Uo, editor. 2020.

54. Kushner Gadarian S, Goodman SW, Pepinsky TB. Partisanship, Health Behavior, and Policy Attitudes in the Early Stages of the COVID-19 Pandemic. In: University S, California-Irvine Uo, University C, editors. 2020.

Publisher's Note Springer Nature remains neutral with regard to jurisdictional claims in published maps and institutional affiliations.

Phillip M. Singer PhD, is an Assistant Professor in the Political Science Department, University of Utah, Salt Lake City, USA

Charley E. Willison PhD, is a Postdoctoral Fellow, Department of Health Care Policy, Harvard University, Boston, Massachusetts, USA.

Scott L. Greer PhD, is a Professor in the Department of Health Management and Policy, University of Michigan School of Public Health, Ann Arbor, Michigan, USA. 